Our Nature (2013), 11(1): 54-60

\title{
Impact on Vegetation due to Deep Drain in Water Valley of South Australia
}

\author{
Sabita Khanal ${ }^{1}$, Xu Zheng ${ }^{2}$, Madhusree Sannigarahi ${ }^{2}$ and Pradip Gyawali ${ }^{2,3 *}$ \\ ${ }^{1}$ Institute of Agriculture and Animal Science, Rampur, Chitwan, Nepal \\ ${ }^{2}$ Flinders University of South Australia, Bedford Park, South Australia, 5046 \\ ${ }^{3}$ University of Queensland, School of Population Health, Herston Road, Herston, Queensland, 4006, Australia \\ EE-mail: pradip.gyawali@uqconnect.edu.au
}

Received: 02.05.2013, Accepted: 15.06.2013

\begin{abstract}
Drains have been widely used to treat dry land salinity and removing excessive water from wetland area. The main aim of this study is to evaluate the impact on vegetation by deep and open drains. Aerial images of two different time interval were evaluated by using dot grid overlaid method. Deep and open drain had significantly changed the vegetation composition of study area. Proportional coverage of bare ground had increased by $132.9 \%$. Conversely, the proportional coverage of lakes, shrubs and grassland had decreased by 26.1 ., 21.1 and $3.9 \%$, respectively. The impact was severe in the wetland landscape in comparison to the pasture landscape.
\end{abstract}

Key words: Vegetation change, Deep drainage, Environmental impact, South Australia

\section{Introduction}

Human settlement is one of the major influencing factors that can significantly change composition of landscape around the world (Antrop, 2000; Giannecchini et al., 2007). People have modified landscape by fire, land clear and infrastructure development according to their interest (Alegre et al., 1986; Nellemann et al., 2003; Stolle et al., 2003). New flora and fauna have introduced into the environment, which had negative impact on local flora and fauna (Frost, 1998; Tait et al., 2005). Australia is one of the continents where environmental composition has strongly manipulated by human settlement in a very short period (Low and Heinen, 1993; Frost, 1998). As a result, various parts of Australia are currently experiencing environmental degradation. It is estimated that almost $90 \%$ of Australian native flora has been lost and there is little or no records of the PreEuropean environmental structure (Taffs, 2001).

Water Valley of Upper South East of South Australia had potential agricultural land. Deep and open drains were started to construct by 1999 to remove excessive water and reduce dry land salinity (Taffs, 2001; DWLBC, 2002) because they were considered as ultimate solution of dry land salinity and promoted in past decade (Ali et al., 2004). As a result, environmental degradation of the area had been increased as well as flora and fauna were decline 
Sabita Khanal, Xu Zheng, Madhusree Sannigarahi and Pradip Gyawali

/ Our Nature (2013) 11(1): 54-60

dramatically. Reduction of water dependent plants and animals was significant. Some species of flora and fauna were brought to the edge of extinction (Tesoriero, 1998). Very few studies were conducted to outline the impact of drainage in the area (Taffs, 2001). Those studies mainly focus on agricultural development (Speight and Nance, 1986) groundwater level (Armstrong and Stadter, 1992), wetland resources (Jensen, 1993), surface water flow (Clark and Kotwicki, 1992). However, no studies were conducted to outline the impact of drainage on composition of vegetation in landscape. The main aim of this study is to identify the vegetation change in landscape level due to deep open drain.

\section{Materials and methods \\ Study area}

The study area (water valley) is situated in the $36^{\circ} 7^{\prime} 41^{\prime \prime}$ south and $139^{\circ} 48^{\prime} 42^{\prime \prime}$ east and about to $250-300 \mathrm{~km}$ from Adelaide city (Fig. 1). The study area used to be a historic wetland with almost $40 \%$ wetland area. Surface water used to flow from south to north lagoon during the rainy season (Tesoriero, 1998). Climate is dry summers and wet winters. The rainfall varies latitudinal with an average of 500 to 550 $\mathrm{mm}$ per year (Jensen, 1993). The vegetation in the area varies from woodlands, open scrub, open heath and herb lands. All of the vegetation associations are found in other areas of the South East. Eight different types of vegetation association are found in the study area (Stewart et al., 1998; Foulkes and Heard, 2003). Trees are poorly represented and only exist in small populations.

\section{Data collection}

This study was conducted in July 2010 to September 2010. Two aerial photographs of different time interval (1999 and 2005) with scaled 1:4000 were obtained from Department of Environment and Heritage (DEH), Adelaide. A common study area was established in both aerial images. The study area was divided in two categories such as wetland (A) and pasture (B) according to their structure. All together (n $=1778)$ hectors, $(\mathrm{n}=1190)$ hectors wetland and $(\mathrm{n}=588)$ hectors pasture area was established for study purpose. The study area was established alongside a deep and open drain. Value of different land cover variables such as drain, lake, road, bare ground, wells, shrubs and grassland was obtained by using dot grid overlay method (Lillesand and Kiefer, 1999). The vegetation structure of the study area before the drain was calculated by using the aerial image of 1999 (Fig. 2). Similarly, aerial image of year 2005 (Fig. 3) was used to calculate the vegetation of the study area after drains were built. All the data obtained from dot grid overlaid method were stored in the Microsoft excel and statistical analysis was conducted by using chi-square test at significant $(\alpha=0.05)$.

\section{Results}

The study showed that, overall landscape (n $=1778$ ) hectors had changed significantly due to deep and open drain. The proportional coverage of bare ground increased from 9.4 to $21.9 \%$ with change of $132.9 \%$. Similarly, construction of road increased and proportional coverage was changed by $44.8 \%$. Lakes were shrunk; shrubs and grassland area were reduced dramatically as result of deep and open drain. The proportional coverage of lakes 
Sabita Khanal, Xu Zheng, Madhusree Sannigarahi and Pradip Gyawali / Our Nature (2013) 11(1): 54-60

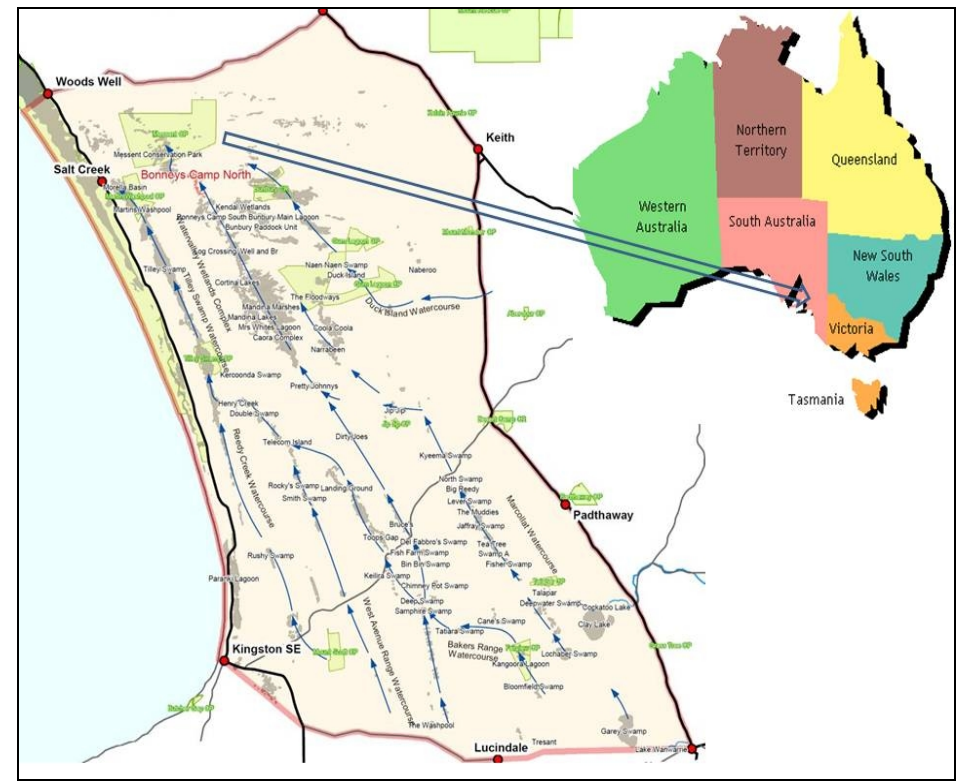

Figure 1. Map of the study area (Upper South East of South Australia).

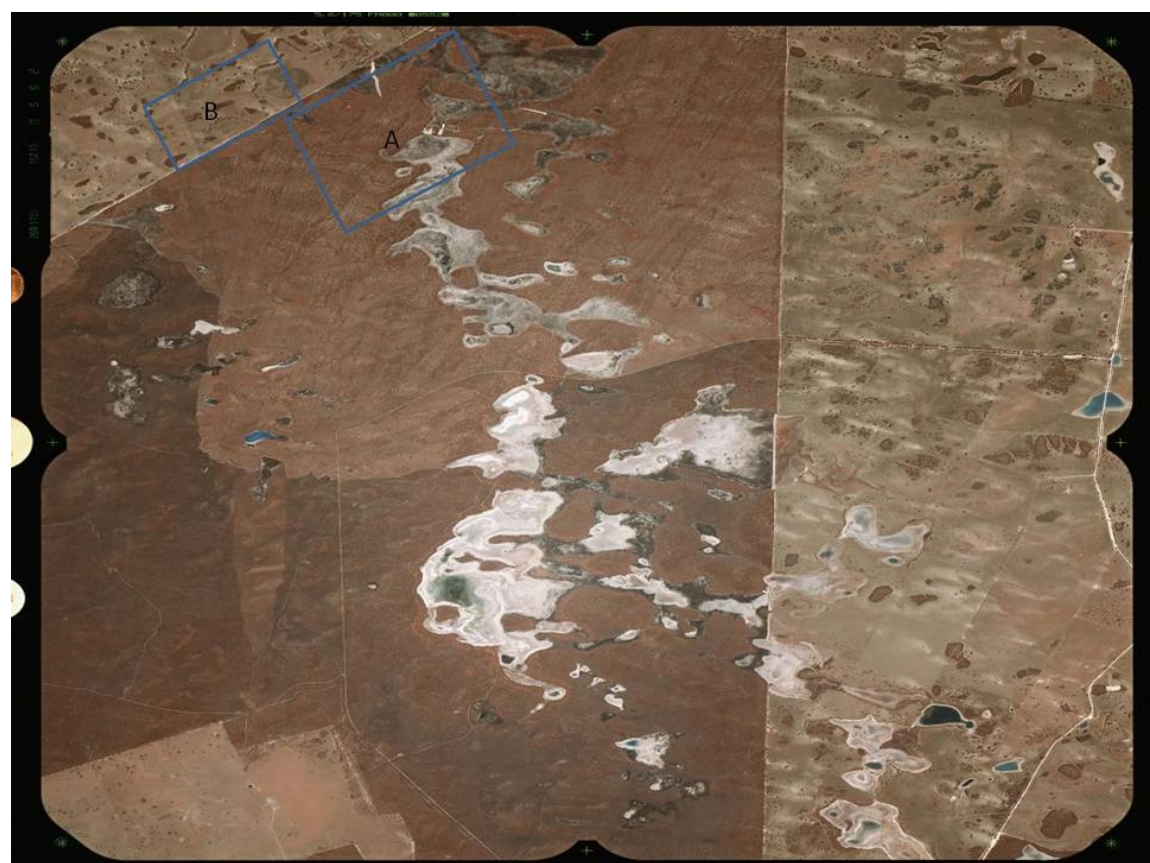

Figure 2. Aerial image of 1999 obtained from DEH (1:4000). 
Sabita Khanal, Xu Zheng, Madhusree Sannigarahi and Pradip Gyawali

/ Our Nature (2013) 11(1): 54-60

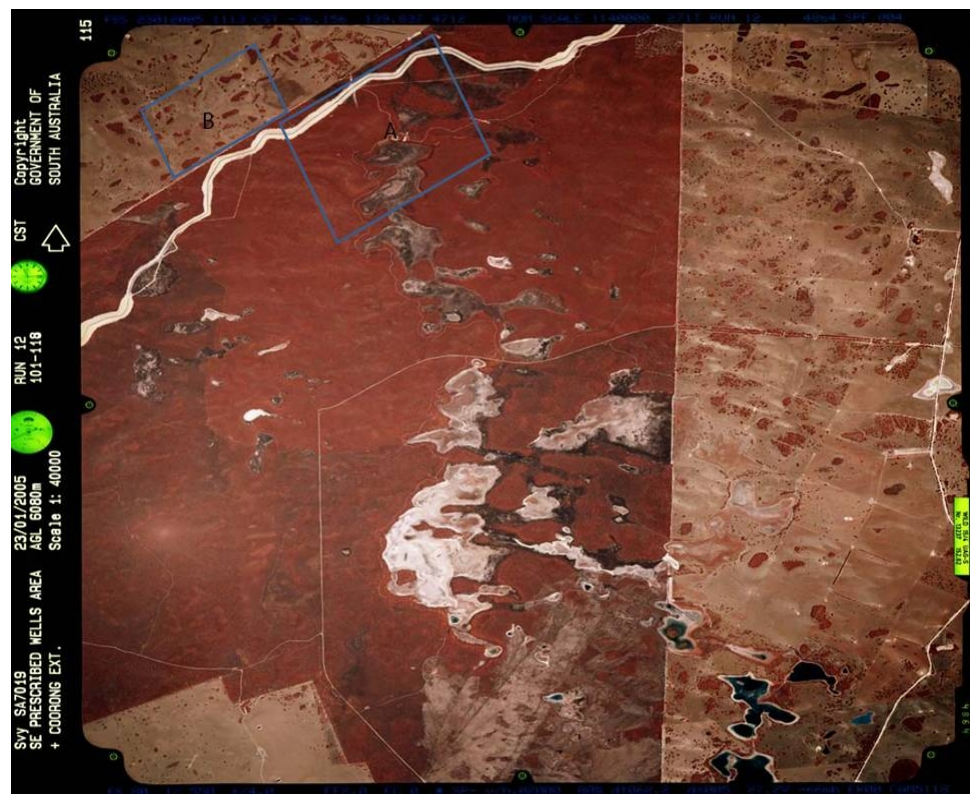

Figure 3. Aerial image of 2005 obtained from DEH (1:4000).

Table 1. Landscape change in overall study area (significant at $\alpha=0.05$ level).

\begin{tabular}{|c|c|c|c|c|c|}
\hline \multirow[b]{2}{*}{ Variables } & \multicolumn{2}{|c|}{1999} & \multicolumn{2}{|c|}{2005} & \multirow{2}{*}{$\begin{array}{c}\text { Change } \\
(\%)\end{array}$} \\
\hline & $\begin{array}{c}\text { Area cover } \\
\text { (ha) }\end{array}$ & $\begin{array}{c}\text { Proportional } \\
\text { cover }(\%)\end{array}$ & Area cover (ha) & $\begin{array}{c}\text { Proportional } \\
\text { cover }(\%)\end{array}$ & \\
\hline Lake/Pond & 212 & 11.9 & 157 & 8.8 & -26.1 \\
\hline Road & 120 & 6.7 & 173 & 9.7 & 44.8 \\
\hline Shrubs & 957 & 53.8 & 748 & 42.1 & -21.1 \\
\hline Grassland & 322 & 18.1 & 310 & 17.4 & -3.9 \\
\hline Bare ground & 167 & 9.4 & 390 & 21.9 & 132.9 \\
\hline
\end{tabular}

Table 2. Landscape change in wetland and pasture area (significant at $\alpha=0.05$ level).

\begin{tabular}{|c|c|c|c|c|c|c|}
\hline \multirow[b]{2}{*}{ Variables } & \multirow[b]{2}{*}{ Area } & \multicolumn{2}{|c|}{1999} & \multicolumn{2}{|c|}{2005} & \multirow{2}{*}{$\begin{array}{c}\text { Change } \\
(\%)\end{array}$} \\
\hline & & $\begin{array}{l}\text { Area cover } \\
\text { (ha) }\end{array}$ & $\begin{array}{c}\text { Proportional } \\
\text { cover }(\%)\end{array}$ & $\begin{array}{c}\text { Area cover } \\
\text { (ha) }\end{array}$ & $\begin{array}{c}\text { Proportional } \\
\text { cover }(\%)\end{array}$ & \\
\hline \multirow[t]{2}{*}{ Lake/Pond } & Wetland & 192 & 16.1 & 143 & 12 & -25.5 \\
\hline & Pasture & 20 & 3.4 & 14 & 2.4 & -29.4 \\
\hline \multirow[t]{2}{*}{ Road } & Wetland & 20 & 1.7 & 84 & 7.1 & 317.6 \\
\hline & Pasture & 100 & 17 & 89 & 15.1 & -11.2 \\
\hline \multirow[t]{2}{*}{ Shrubs } & Wetland & 697 & 58.6 & 577 & 48.5 & -17.2 \\
\hline & Pasture & 260 & 44.2 & 171 & 29.1 & -34.2 \\
\hline \multirow[t]{2}{*}{ Grassland } & Wetland & 190 & 16 & 132 & 11.1 & -30.6 \\
\hline & Pasture & 132 & 22.5 & 178 & 30.3 & 34.7 \\
\hline \multirow[t]{2}{*}{ Bare ground } & Wetland & 91 & 7.6 & 254 & 21.3 & 180.3 \\
\hline & Pasture & 76 & 12.9 & 136 & 23.1 & 79.1 \\
\hline
\end{tabular}


Sabita Khanal, Xu Zheng, Madhusree Sannigarahi and Pradip Gyawali

/ Our Nature (2013) 11(1): 54-60

observed negatively $26.1 \%$. Similarly, the proportional coverage of shrubs and grassland had reduced by $21.7 \%$ and $3.9 \%$, respectively as a result of deep drains (Tab. 1). Overall change in landscape of the study area was found to be statistically significant $(\mathrm{p}<0.05)$.

The proportional cover of road and bare ground increased from 1.7 to $7.1 \%$ and 7.6 to $21.3 \%$ in wetland area. But the proportion coverage of grassland, shrub and lake decreased from 16 to $11.1 \%, 58.6$ to $48.5 \%$ and 16.1 to $12 \%$, respectively. The area coverage change in wetland area was statistically significant $(\mathrm{p}<0.05)(\mathrm{Tab} .2)$. The proportional coverage of bare ground and grassland of pasture area increased from 12.9 to $23.1 \%$ and 22.5 to $30.3 \%$. Conversely, the proportional coverage of shrub and lake and road decreased from 44.2 to $29.1 \%, 3.4$ to $2.4 \%$ and 17 to $15.1 \%$, respectively. The area coverage change in pasture area was statistically significant $(\mathrm{p}<0.05)$ (Tab. 2).

\section{Discussion}

Deep and open drains were used to flush dry land salinity (Ali et al., 2004) and remove excessive water from the pasture land (Armstrong and Stadter, 1992) across the globe. This study showed that, deep and open drains had played significant role on increasing proportional coverage of bare ground and road. On the other hand, deep and open drains were also responsible for reducing the proportional coverage of lake, shrubs and grassland. This might be the case of excavating drains and keeping underground soil in both side of drain. Heavy machinery and equipment could be used to dig those big and deep drains. Road networks were essential to transport to the digging area. That may increased the proportional coverage of road and bare ground in the study area.

The Australian landscape is heavily depends on climatic conditions (Hatton and Nulsen, 1999). Past few years Australia had worse drought. Average rain fall around the country including the study area decreased dramatically (Taffs, 2001). Deep and open drain had significant role on removing ground water quicker during dry season (Armstrong and Stadter, 1992). According to (Ali et al., 2004) drains deeper than $2 \mathrm{~m}$ were capable to remove the surface water from up to $300 \mathrm{~m}$ both side. The drains were constructed close to lakes; this could have significant role on removing water from lakes. As a result lakes can be dried out and transformed in to the bare ground and decreasing proportional coverage of lakes. This might be the significant cause of reducing the proportional coverage of lakes and increasing the proportional coverage of bare ground.

This study showed that the proportional coverage of bare ground impacted higher $(180.3 \%)$ in wetland area in comparison to the $(79.1 \%)$ in pasture area. This also showed the deep and open drains were responsible for removing water from lakes and changing the structure of landscape. Similarly, most of the drains were constructed through wetland area which has increased the soil dumping ration on to the side of drains. This study also showed that proportional coverage of road was increased by $(317.6 \%)$ in the wetland area. However, the coverage was decreased $(11.2 \%)$ in pasture area. This could be the result of constructing new temporary roads on wetland area to transport digging machinery. However, people had road 
Sabita Khanal, Xu Zheng, Madhusree Sannigarahi and Pradip Gyawali

/ Our Nature (2013) 11(1): 54-60

network on the pasture area before construction of deep open drains. Once road were constructed through wetland area community people started using those newly constructed roads instead of roads on pasture area. As a result grass could cover the edges of those abundant roads (Barson et al., 2000).

This study showed that the proportional coverage of grassland had increased by $34.7 \%$ in the pasture area however decreased by $30.6 \%$ in the wetland area. This might be the result of shifting roads from pasture area to the wetland area because grass could grow on the temporary road in pasture area over the time. On the other hand, Lack of water might resulted higher proportion of water dependant grass died off. According to the (Tesoriero, 1998; Taffs, 2001) lack of water in a lake can result the loss of aquatic and semi aquatic grass. That might be the cause of decreasing proportional coverage of grassland in the wetland area. Furthermore, construction of the drains, road and dumped soil at the bank of drains also reduce the proportional coverage of grassland in wetland area. Deep and open drains had resulted $34.2 \%$ reduction of shrubs in wetland area and $17.2 \%$ reduction in pasture area. After construction of deep drain people started developing big sheep and cattle farm in the pasture area. Those domestic animals might smothered shrubs and create big open field with small grass. Similarly, after removing water from lake water dependant shrubs might dry out. In addition to that wildlife can easily walk around the lake and run over the shrubs. That might cause the reduction of shrubs in the both area.

\section{Conclusion}

Deep drains are responsible for degradation of landscape in the upper south east of South Australia. This study showed that the environment health of the wetland area had damaged almost irreversible by extinction of some flora. Constructing dams in the drains might help to regulate the water flow. However, further studies require understanding the underground hydrology of the area.

\section{Acknowledgements}

We would like to thank DEH for their support and providing best quality aerial images of study area. We are thankful to Professor David Bass, Flinders University for his inspiration to peruse this study.

\section{References}

Alegre, J., D. Cassel and D. Brandy 1986. Effects of land clearing and subsequent management on soil physical properties. Soil Science Society of America Journal 50: 1379-1384.

Ali, R., T. Hatton, R. George, J. Byren and G. Hodgson 2004. Evaluation of the impacts of deep open drains on groundwater levels in the wheatbelt of Western Australia. Crop and Pasture Science 55: 1159-1171.

Antrop, M. 2000. Background concepts for integrated landscape analysis. Agriculture, Ecosystems and Environment 77: 17-28.

Armstrong, D. and F. Stadter 1992. Computer modelling to examine the performance of groundwater drains. Department of Mines and Energy, Adelaide.

Barson, M., L. Randall and V. Bordas 2000. Land cover change in Australia. Results of the collaborative Bureau of Rural Sciences-State agencies' project on remote sensing of land cover change. Bureau of Rural Sciences, Canberra.

Clark, R. and V. Kotwicki 1992. Surface water hydrology: Environmental Impact Statement Background Paper for the Upper South East Dryland Salinity and Flood Management Plan 


\section{Sabita Khanal, Xu Zheng, Madhusree Sannigarahi and Pradip Gyawali / Our Nature (2013) 11(1): 54-60}

Steering Committee. Engineering and Water Supply Department, Adelaide.

DWLBC. 2002. Upper South East Dryland Salinity and Flood Management Act 2002 Quarterly Report. Department of Water, Land and Biodiversity Conservation, Adelaide.

Foulkes, J. and L. Heard 2003. A Biological Survey of the South East, South Australia, 1991 and 1997. Department for Environment and Heritage, South Australia.

Frost, W. 1998. European farming, Australian pests: Agricultural settlement and environmental disruption in Australia, 1800-1920. Environment and History 4: 129-143.

Giannecchini, M., W. Twine and C. Vogel 2007. Land-cover change and human-environment interactions in a rural cultural landscape in South Africa. The Geographical Journal 173: 26-42.

Hatton, T. J. and R. A. Nulsen 1999. Towards achieving functional ecosystem mimicry with respect to water cycling in southern Australian agriculture. Agroforestry Systems 45: 203-214.

Jensen, A. 1993. Assigning values to wetlands and natural resources in the South East of South Australia. A background paper prepared for the Upper South East Dryland Salinity and Flood Management Plan Environmental Impact Statement. Department of Environment and Land Management, Adelaide.

Lillesand, T. and R. Kiefer 1999. Remote sensing and image interpretation. John Wiley and Sons, New York.

Low, B.S. and J.T. Heinen 1993.Population, resources and environment: implications of human behavioral ecology for conservation. Population and Environment 15: 7-41.

Nellemann. C., I. Vistnes, P. Jordhoy, O. Strand and A. Newton 2003. Progressive impact of piecemeal infrastructure development on wild reindeer. Biological Conservation 113: 307-317.

Speight, D.L. and C. Nance 1986. A land transformed: environmental change in South Australia. Longman Cheshire, Melbourne.

Stewart, H., H. Owens, G. Carpenter and T. Croft 1998. A biological survey of Bunbury Conservation Reserve and Stoneleigh Park Heritage Agreement South Australia. Department for Environment, Heritage and Aboriginal Affairs. Adelaide, Australia.

Stolle, F., K. Chomitz, E. Lambin and T. P. Tomich 2003. Land use and vegetation fires in Jambi Province, Sumatra, Indonesia. Forest Ecology and Management 179: 277-292.

Taffs, K.H. 2001. The role of surface water drainage in environmental change: a case example of the Upper South East of South Australia, an historical review. Australian Geographical Studies 39: 279 301.

Tait, C.J., C.B. Daniels and R.S. Hill 2005. Changes in species assemblages within the Adelaide Metropolitan Area, Australia, 1836-2002. Ecological Applications 15: 346-359.

Tesoriero, J. 1998. Factors affecting the distribution and abundance of common wombat (Vombatus ursinus) in upper South East of South Australia. Honours, University of South Australia. 